\title{
Protura (Arthropoda: Hexapoda) in Slovenian caves
}

\author{
Loris Galli (D 1*, Franc Janžekovič (D) ${ }^{2}$, Peter Kozel (DD ${ }^{2,3,4}$, Tone Novak ${ }^{2}$ \\ ${ }^{1}$ Department of Earth, Environment and Life Sciences (DISTAV) - Genoa University, Corso Europa 26, 16132 Genova, Italy \\ ${ }^{2}$ Department of Biology, Faculty of Natural Sciences and Mathematics, University of Maribor, Koroška cesta 160, 2000 Maribor, Slovenia \\ ${ }^{3}$ Bureau of Economic Geology, University Station, Box X, University of Texas at Austin, TX 78713-8924, USA \\ ${ }^{4}$ UNESCO Chair on Karst Education, University of Nova Gorica, Glavni trg 8, 5271 Vipava, Slovenia
}

\begin{abstract}
Protura is a small class of Hexapoda, generally poorly known, and rather scarce data on its occurrence in caves are scattered throughout literature on fauna in caves and in some papers on Protura. Although the cave-dwelling fauna is relatively well studied in Slovenia, published records on Protura are rare. In this paper, data on the occurrence and abundance of Protura in Slovenian caves are considered. Various statistical analyses were performed to compare caves with Protura to those without in 60 intensively monitored cavities to detect any differences in the selected environmental conditions. No significant difference was obtained. Samples collected from 15 caves yielded 286 specimens identified to genus or species level. Ten species were identified: Acerentulus confinis (Berlese, 1908), A. rafalskii Szeptycki, 1979*, Acerentomon affine Bagnall, 1912* A. balcanicum lonesco, 1933* ${ }^{*}$ A. italicum Nosek, 1969, A. maius Berlese, 1908* A. meridionale Nosek, 1960, Acerella muscorum (Ionesco, $1930)^{*}$, Eosentomon armatum Stach, $1926^{*}$ and E. transitorium Berlese, 1908*. The seven species marked with an asterisk are new records for Slovenia. Two specimens belonging to an unidentified species of the genus lonescuellum Tuxen, 1960 were also found. As expected, Protura were most abundant at the cave entrance close to the surface, and none of the species were found exclusively in cavities. This suggests that proturans were introduced passively into the cavities via organic matter and surface soils.
\end{abstract}

Keywords: $\quad$ adaptations, cave fauna, microarthropods, microhabitats, subterranean ecosystem Received 7 February 2021; Revised 5 March 2021; Accepted 5 March 2021

Citation: Galli L., Janžekovič F., Kozel P. and Novak T., 2021. Protura (Arthropoda: Hexapoda) in Slovenian caves. International Journal of Speleology, 50 (1), 65-74. Tampa, FL (USA) ISSN 0392-6672 https://doi.org/10.5038/1827-806X.50.1.2380

\section{INTRODUCTION}

Protura is a small, poorly known Class of Hexapoda. In particular, knowledge of their geographical distribution is strongly biased, partly due to the "proturologists" distribution effect (Galli \& Rellini, 2020). This means that the observed distribution of proturans largely reflects the presence of specialists in different geographical areas, rather than a real biogeographical pattern. The same bias has been observed in other soil- and cave-dwelling organisms, such as palpigrades (Mammola et al., in press) and diplurans (Sendra et al., 2020). Previously, only nine species of Protura had been identified from a few localities in Slovenia (Nosek, 1973; Szeptycki, 2007; Galli et al., 2016): Acerentulus condei Nosek, 1983, A. confinis (Berlese, 1908), Acerentomon doderoi Silvestri, 1907, A. kustorae Nosek, 1983, A. italicum Nosek, 1969, A. meridionale Nosek, 1960, A. microrhinus Berlese, 1909, Acerella tiarnea (Berlese, 1908) (doubtful record) and Eosentomon delicatum
Gisin, 1945. Among these, two species were described from Slovenian type material: A. kustorae and A. meridionale. To date, the former is known only from the type locality (Szeptycki, 2007).

Protura ecology is also poorly known; however, these euedaphic microarthropods mainly, if not exclusively, feed on fungal hyphae (see Galli et al., 2019a, b). Some records of these organisms from caves are known from general faunistic papers (Vandel, 1964; Neuherz, 1974, 1975; Nosek, 1975; Novak, 2005; Szeptycki, 2007; Galli et al., 2019b; Shrubovych \& Georgiev, 2020), but no specialized subterranean, troglobiotic species has been described (Pass \& Szucsich, 2011). However, Nosek (1977a,b) stated that Protura "were introduced also into caves" and that the only adaptation recorded to the "troglodytic mode of life" was an "enlargement of body size". However, this notation is missing any further clarifications and has not been supported by further bibliographic reports. Generally, Protura are morphologically uniform, as observed between populations of the same species 
living in different environments and climates, and after long times of separate evolution (Nosek, 1975; Tuxen, 1978). Further, none of the papers published to date has dealt specifically with Protura in caves.

In general, due to difficulties in exploring and studying subterranean environments, knowledge about the subterranean fauna is largely incomplete (Mammola, 2018). A significant proportion of subterranean species are still undescribed (the Linnean shortfall), and the distribution of already described species (the Wallacean shortfall), their abundances and population dynamics (the Prestonian shortfall) are mostly unknown (Cardoso et al., 2011; Culver et al., 2012; Ficetola et al., 2018). However, the subterranean fauna in Slovenian caves is relatively well known and has been recognized globally as unique and a biodiversity hotspot for richness in troglobiont species along the "mid-latitude biodiversity ridge in terrestrial cave fauna" (Bole et al., 1993; Culver et al., 2006; Culver \& Pipan, 2019). Yet, some taxa remain significantly understudied, and some other taxa, such as Protura, have never been studied in association with cave ecosystems.

In the present paper we provide the first comprehensive faunistic and ecological data on Protura in caves. We give a general overview of proturan distribution in intensively explored caves in Slovenia, and, for some caves, provide a more in-depth taxonomic analysis. Furthermore, we compare the environmental conditions in caves with and without proturans, and investigate the influence of the main cover types and the slope azimuth where the caves are located on the occurrence of Protura in caves. In addition, we present data on ecological conditions in cave sections where Protura have been found, and a general pattern of their spatial distribution in caves.

\section{METHODS}

\section{Field methods}

Since 1977, 64 cavities (caves and artificial tunnels) in northern and central Slovenia have been the object of ecological studies in January, April, July, and October, following a standardized sampling scheme (Novak, 2005). Most of these cavities are figured in Novak (2005), two further in Novak et al. (2004b) and Kozel et al. (2019). General data on caves were obtained from the Cave Cadastre (Slovenian Speleological Society), while for short caves not registered in the Cadastre, and for artificial cavities, our own data were provided. For simplicity, both caves and artificial cavities will be referred to as caves in the following text. Caves were divided into 785 sampling sections in total, with an average length of $\sim 4 \mathrm{~m}$ each, i.e. an average of 12 sampling sections each. The distances from the entrance (polygonal distance) and from the surface (vertical distance) to the center of the sampling sections were calculated from the cave ground plan and the terrain profile above the cave, rounded up to $1 \mathrm{~m}$ accuracy each. Once per season, we took records of air temperature and relative air humidity in every sampling section using a psychrometer (initially an August psychrometer, later a handheld aspiration psychrometer Ahorn FN A846, Germany). A mercury thermometer, and a probe thermometer (Checktemp 1, Hanna, Germany), were used to measure the ground temperature at a depth of $2 \mathrm{~cm}$. The substrate moisture content was determined after drying 100 g samples at $105^{\circ} \mathrm{C}$ until reaching the stable weight (Sheppard \& Addison, 2008). Environmental factors that change only negligibly over the year in caves were measured only once (Kozel et al., 2019). Among these, the $\mathrm{pH}$ of the ground substrate was measured with a pH meter (91-02 Orion, USA Orion Ionalyser 407 A; Hanna Instruments HI221 Calibration Check, Microprocessor $\mathrm{pH}$ Meter), and the carbonate content in the substrate by means of Scheibler's calcimetry. Organic material content was calculated after the ignition of dry substrate samples $\left(\right.$ at $650^{\circ} \mathrm{C}$ ) (Halikia et al., 2001) in a muffle furnace. Airflow was measured with a hand-held anemometer (Munro IM159) or - with all values lower than $0.3 \mathrm{~ms}^{-1}$ not measurable with the anemometer - derived from the velocity of fog or smoke of a burned match or magnesium belt (Novak et al., 2004a). The main cover type (pine, deciduous, mixed wood, scrubland, meadow, bare rock) in the landscape around the cave was determined on the first visit. The slope azimuth in front the cave was determined on 1:25.000 maps.

\section{Protura sampling, preparation and identification}

A two-day exposure to baited pitfall traps (decomposing beef and apple juice, with a lacing of cherry and maraschino essence, and a few drops of detergent to reduce the surface tension), and BerleseTullgren funnel extraction of $100 \mathrm{~g}$ samples from a $\sim 0.25 \mathrm{~m}^{2}$ area around the pitfall traps were applied in the study. In total, 3140 trap samples and 3092 Berlese-Tullgren samples were collected. For details see Novak (2005) and Kozel et al. (2019). Some other collecting methods, such as large Berlese-Tullgren funnel extraction, were only qualitatively analyzed as they were unsuitable for quantitative analysis. However, proturans extracted by means of such methods were studied and analyzed taxonomically (e.g., those from caves IDs 3 and 28). Voucher specimens of Protura were deposited in the zoological collection of DISTAV - University of Genova (Protura series: 479, 481-487, 724-731, 773-776). Protura collected in 15 of the caves listed in Table 1 (IDs: 3, $28,31,32,35,36,37,38,40,42,45,48,49,52$, and 59) were prepared for species identification. For this purpose, they were incubated at $40-50^{\circ} \mathrm{C}$ for 24 hours in lactic acid to make them clear, then mounted on slides in Marc André II medium. Specimens were observed and identified to species and life-stage levels with the aid of an interference contrast microscope (Leica DM LB2), a Leica DFC 295 camera, and Leica Application Suite Vers. 3.8.

\section{Statistical analyses}

To compare environmental conditions between caves with and without proturans, 60 caves were evaluated, consisting of subequal numbers of both cave groups; 31 with and 29 without proturans (Table 1, Fig. 1) regardless of their natural $(n=56)$ or artificial origin 
$(\mathrm{n}=4)$, since the relative faunas are quite comparable (Pretner, 1979). A Mantel test was applied to check for the spatial autocorrelation among caves with and without Protura using an ade4 package (Dray et al., 2020). Due to the small number of Protura available and bearing in mind that their ecology is poorly known but probably similar in various species (Galli et al., 2019 a,b) the analyses were carried out on the entire sample (for support in this regard, see Qiao et al., 2017; Smith et al., 2019).

Table 1. Cavities included in the analysis of the ecospace properties with Protura; 31 caves with and 29 caves without Protura. Cad. Nr, Cadastre number of the cavity; Presence (1)/absence (0) of Protura; N, E, coordinates; Elev., elevation of the (main) entrance [m]; Length res., length of the studied part of the cave [m]; Slope dir., direction of the slope on which the cave opens; n.r. not yet registered; * artificial cavity.

\begin{tabular}{|c|c|c|c|c|c|c|c|c|}
\hline ID & Cavity & Protura & Cad. Nr. & $\mathbf{N}$ & $\mathbf{E}$ & Elev. & $\begin{array}{l}\text { Length } \\
\text { res. }\end{array}$ & Slope dir. \\
\hline 1 & Jama pri taboru & 0 & 367 & 46.28 & 14.24 & 463 & 42 & 100 \\
\hline 2 & Babja luknja & 0 & 35 & 46.13 & 14.39 & 330 & 85 & 50 \\
\hline 3 & Jama 2 na Jurcetovih Percah & 0 & 2327 & 46.10 & 14.42 & 408 & 42 & 140 \\
\hline 4 & Zijalka nasproti Ribče peči & 0 & 4605 & 46.42 & 14.62 & 820 & 50 & 30 \\
\hline 5 & Korančevka & 0 & 2503 & 46.48 & 14.78 & 1010 & 54 & 250 \\
\hline 6 & Lovrišnikova jama & 0 & 758 & 46.15 & 14.80 & 480 & 12 & 190 \\
\hline 7 & Jama pri Votli peči pri Ravnah & 0 & 3263 & 46.55 & 14.97 & 388 & 22 & 0 \\
\hline 8 & Skobirjeva votlica & 0 & 3956 & 46.47 & 14.98 & 940 & 25 & 80 \\
\hline 9 & Mesarska lopa & 0 & 563 & 46.38 & 14.90 & 1279 & 40 & 180 \\
\hline 10 & Brdajsova jama & 0 & 3497 & 46.12 & 14.90 & 651 & 28 & 120 \\
\hline 11 & Lokoviška jama & 0 & 3959 & 46.37 & 15.02 & 360 & 45 & 300 \\
\hline 12 & Jama v Burgi & 0 & 1091 & 46.08 & 15.02 & 600 & 15 & 150 \\
\hline 13 & Zapečke peči & 0 & 3208 & 46.55 & 15.22 & 610 & 20 & 180 \\
\hline 14 & Kapelarjevo brezno & 0 & 4706 & 46.11 & 15.21 & 440 & 25 & 130 \\
\hline 15 & Fantovska luknja 2 & 0 & 3967 & 46.22 & 15.31 & 420 & 56 & 0 \\
\hline 16 & Umetni rov nad Šturmovo grabo* & 0 & U3 & 46.60 & 15.46 & 624 & 58 & 100 \\
\hline 17 & Jama v kamnolomu pri Suhem & 0 & 4632 & 46.14 & 15.39 & 500 & 25 & 200 \\
\hline 18 & Glija jama & 0 & 84 & 46.11 & 15.44 & 515 & 68 & 0 \\
\hline 19 & Jama 2 v Repoluskovih pečinah & 0 & 4371 & 46.68 & 15.62 & 492 & 20 & 200 \\
\hline 20 & Gruska jama & 0 & 1374 & 46.09 & 15.57 & 310 & 22 & 200 \\
\hline 21 & Jama pod južnim vrhom Tisnika & 0 & 521 & 46.41 & 15.17 & 728 & 25 & 80 \\
\hline 22 & Železna jama & 0 & 2678 & 46.14 & 14.64 & 344 & 86 & 200 \\
\hline 23 & Jernejeva jama & 0 & 929 & 45.72 & 14.16 & 610 & 63 & 60 \\
\hline 24 & Mala jama v Kostanjeviški jami & 0 & 518 & 45.84 & 15.43 & 170 & 70 & 150 \\
\hline 25 & Jama Kreščak & 0 & 5849 & 45.85 & 15.64 & 298 & 170 & 250 \\
\hline 26 & Karbelova jama & 0 & 10411 & 46.63 & 15.01 & 660 & 96 & 80 \\
\hline 27 & Krivčeva jama & 0 & 9238 & 46.24 & 15.76 & 540 & 73 & 160 \\
\hline 28 & Knapovca & 0 & n.r. & 46.63 & 15.55 & 380 & 23 & 70 \\
\hline 29 & Spodnja Stopenca & 0 & 469 & 45.97 & 15.51 & 279 & 55 & 270 \\
\hline 30 & Štinetova jama & 1 & 240 & 46.19 & 14.30 & 395 & 52 & 0 \\
\hline 31 & Godova jama & 1 & 3462 & 46.08 & 14.25 & 528 & 25 & 220 \\
\hline 32 & Lisičja luknja & 1 & 401 & 46.14 & 14.51 & 535 & 20 & 180 \\
\hline 33 & Rački pekel & 1 & 465 & 46.39 & 14.72 & 590 & 38 & 200 \\
\hline 34 & Zijalka v Dovji Griči & 1 & 376 & 46.30 & 14.67 & 1526 & 26 & 130 \\
\hline 35 & Boštonova jama & 1 & 357 & 46.14 & 14.68 & 325 & 30 & 270 \\
\hline 36 & Ihanšica & 1 & 46 & 46.12 & 14.65 & 416 & 56 & 200 \\
\hline 37 & Zamernikova jama & 1 & $\mathrm{~B} 2$ & 46.40 & 14.78 & 857 & 8 & 180 \\
\hline 38 & Podkrajnikova zijalka & 1 & 2697 & 46.27 & 14.78 & 820 & 28 & 280 \\
\hline 39 & Krapljetova jama & 1 & 484 & 46.28 & 14.96 & 854 & 65 & 40 \\
\hline 40 & Jama v Lipovici & 1 & 1182 & 46.16 & 14.89 & 510 & 58 & 220 \\
\hline 41 & Umetni rov v Dravogradu* & 1 & $\mathrm{U} 1$ & 46.58 & 15.02 & 349 & 25 & 90 \\
\hline 42 & Objekt pri Žnodru & 1 & $\mathrm{~B} 1$ & 46.51 & 15.05 & 511 & 7 & 350 \\
\hline 43 & Rdečka jama & 1 & 3488 & 46.45 & 15.01 & 858 & 67 & 10 \\
\hline 44 & Tajnšekova jama 2 & 1 & 2535 & 46.31 & 15.08 & 325 & 15 & 0 \\
\hline 45 & Umetni rov v Bistriškem grabnu* & 1 & $\mathrm{U} 2$ & 46.64 & 15.13 & 437 & 15 & 210 \\
\hline 46 & Jama Školjka & 1 & 3311 & 46.41 & 15.17 & 552 & 44 & 100 \\
\hline 47 & Zgornja Steska jama & 1 & 169 & 46.31 & 15.16 & 374 & 102 & 180 \\
\hline 48 & Špegličeva jama & 1 & 3512 & 46.30 & 15.19 & 400 & 46 & 50 \\
\hline
\end{tabular}




\begin{tabular}{|l|c|c|c|c|c|c|c|c|}
\hline 49 & Ocvirkova jama v Štadlerjevem gozdu & 1 & 5348 & 46.21 & 15.21 & 333 & 40 & 330 \\
\hline 50 & Jama pod Herkovimi pečmi & 1 & 1849 & 46.63 & 15.26 & 538 & 75 & 90 \\
\hline 51 & Jaklova luknja & 1 & 4636 & 46.48 & 15.28 & 1050 & 7 & 150 \\
\hline 52 & Lindeška jama & 1 & 2304 & 46.35 & 15.32 & 525 & 12 & 220 \\
\hline 53 & Luknja pri Naceku na Planici & 1 & 2407 & 46.47 & 15.56 & 735 & 10 & 180 \\
\hline 54 & Jama v kamnolomu nad Studenicami & 1 & 252 & 46.30 & 15.62 & 400 & 32 & 310 \\
\hline 55 & Rov & 1 & 1375 & 46.16 & 15.59 & 315 & 102 & 80 \\
\hline 56 & Jama pri Pruhu & 1 & 4380 & 46.52 & 15.72 & 295 & 107 & 290 \\
\hline 57 & Pavlijeva luknja & 1 & 3142 & 46.62 & 15.23 & 595 & 122 & 50 \\
\hline 58 & Ovčje peklo nad Radljami & 1 & 3192 & 46.62 & 15.24 & 520 & 44 & 140 \\
\hline 59 & Umetni rov v Osku* & 1 & $\mathrm{U} 5$ & 46.58 & 15.92 & 262 & 85 & 0 \\
\hline 60 & Zguba jama & 1 & 6290 & 45.80 & 14.21 & 561 & 122 & 270 \\
\hline
\end{tabular}

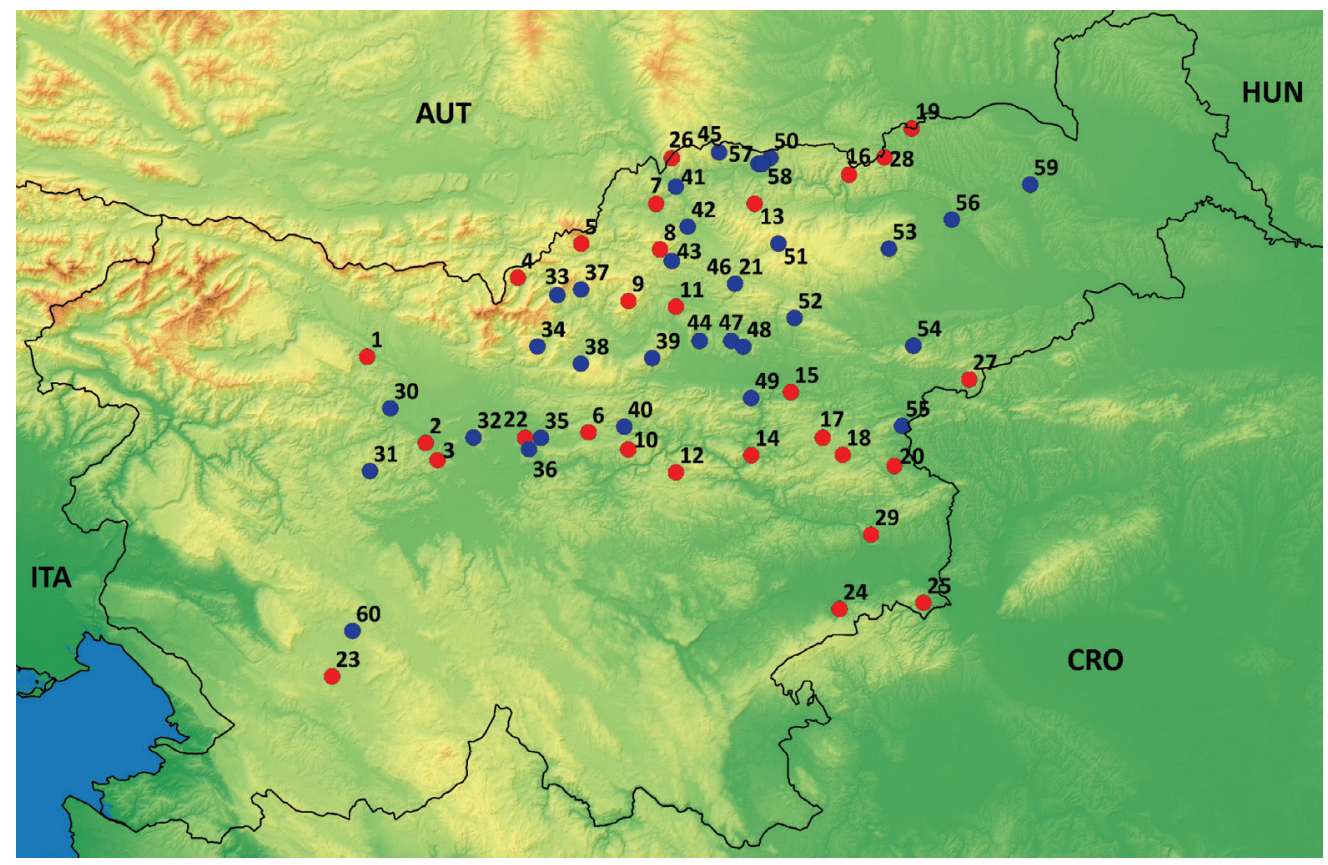

Fig. 1. Map of studied cavities with (blue dots) and without (red dots) Protura in Slovenia. The numbers correspond to the IDs in Table 1.

The dimensionality due to seven ecological variables (Table 2) was reduced using Principal Component Analysis (PCA); all variables were transformed by $z$-standardization before incorporation. Using the ordination method, the multidimensionality of the ecological variables was presented in a twodimensional ecospace, defined by the first and second ecological principal components (EPC1 and EPC2). Differences in the ecospace between sampling sections, with Protura and without Protura, were checked by subjecting EPC1 and EPC2 to a t-test. Ecospaces for the sampling sections, with and without Protura, were graphically presented with a biplot on EPC1 and EPC2 and polygons of the ecospaces were presented using the Convex Hull method. The PCA was conducted in $\mathrm{R}$ environment in package factoextra (Kassambara \& Mundt, 2020). The graphic projection of ecospaces on the first two ECPSs and the application of Convex Hulls were performed using software PAST version 4.02 (Hammer et al., 2001). For this analysis, we used data from the first two sampling sections, i.e., $\sim 5 \mathrm{~m}$ inside the cave, as the majority of specimens were recorded there.

Preliminarily, we tested the presence-absence of Protura with respect to the environmental factors using Binomial Generalized Linear Model (GLM); none of the factors had a statistically significant effect on their presence. Therefore, we checked whether the presence of Protura in the caves coincided with the main cover types in the landscape surrounding the cave. For this purpose, differences between the frequencies of habitat types with respect to the presence/absence of Protura were tested using the Chi square test. In addition, the Watson-Williams test for equal means and the Mardia-Watson-Wheeler test for equal distributions were used to check whether the presence of Protura in the cavities could be explained by orientation of the slopes on which the caves open. All three tests were performed in PAST version 4.02 (Hammer et al., 2001).

In order to investigate the general pattern of spatial distribution of Protura, the influence of the distance from the entrance, and of the distance from the surface on their abundance was examined using a GLM. Abundance was modeled using a negative binomial distribution family, the distribution-type recommended for overdispersed count data (Zuur et al., 2009), using MASS package (Ripley et al., 2020). In the models, only caves with Protura were included by pooling the data for each sampling section up to the deepest part of the caves (i.e., $24 \mathrm{~m}$ from the entrance and $20 \mathrm{~m}$ from the surface), where Protura 
were recorded. Regression analyses were conducted in $\mathrm{R}$ environment ( $\mathrm{R}$ CoreTeam, 2020) following the general protocol by Zuur \& Ieno (2016).

Protura were putatively not attracted by the baits in pitfall traps, and displaced for short distances (speculatively $\sim 0.5 \mathrm{~m}$ only - see also Balkenhol, 1996) during trapping in the caves. Consequently, the trapping results refer to $\sim 1 \mathrm{~m}^{2}$, and densities per $\mathrm{m}^{2}$ were estimated using the following calculation:

$$
\text { Density }=\mathrm{N}_{\text {trap }}+4 \mathrm{~N}_{\text {funnel }}
$$

where $\mathrm{N}_{\text {trap }}$ and $\mathrm{N}_{\text {funnel }}$ are the number of individuals in a trap and Berlese-Tullgren sample, respectively.

The age-ratios (juveniles/adults) of identified specimens in different seasons were compared applying the Chi-square test to the numbers of juveniles (from larva I to pre-imago instar) and adults recorded each season. The statistical significance of the differences from the expected value (1) of the species sex ratio (males/females) was determined using the Chi-square test. Software PAST version 4.02 (Hammer et al., 2001) was used in both cases.

Table 2. Factor loadings from the first two ecological principal components (EPC), and eigenvalues and percentage of explained variation. Loadings $>0.60$ are in bold. The acronyms of ecological variables are explained in Table 3.

\begin{tabular}{|l|c|c|}
\hline \multicolumn{1}{|c|}{ Ecological variables } & EPC1 & EPC2 \\
\hline Tair & $\mathbf{0 . 6 9}$ & $\mathbf{0 . 6 6}$ \\
\hline Tgr & $\mathbf{0 . 6 3}$ & $\mathbf{0 . 6 5}$ \\
\hline RH & -0.53 & -0.25 \\
\hline MC & $\mathbf{- 0 . 6 3}$ & 0.45 \\
\hline pHgr & 0.40 & -0.43 \\
\hline CC & 0.42 & $\mathbf{- 0 . 6 1}$ \\
\hline OM & $\mathbf{- 0 . 6 3}$ & 0.45 \\
\hline Eigenvalue & 2.30 & 1.90 \\
\hline Variance \% & 32.90 & 27.10 \\
\hline
\end{tabular}

\section{RESULTS}

Proturans were collected in 31 cavities and records of 135 individuals were eligible for statistical analyses in relation with environmental data. The descriptive statistics of the environmental conditions in sampling sections with Protura is presented in Table 3. The Mantel test revealed no spatial autocorrelation among caves with and without Protura $(r=-0.001, p=0.397)$.
Most of the seven ecological variables were correlated with each other. To avoid redundancy, these variables were reduced using PCA. The factor loadings and the amount of the explained variance for the first two ecological principal components (EPCs) are shown in Table 2. Increasing EPC1 is associated with an increase in air temperature and ground substrate temperature $(r>0.5)$, and with a decrease in air humidity, substrate moisture content, and organic material content $(\mathrm{r}<-0.5)$ (Table 2). Increasing EPC2 is well associated with an increase in the air temperature and ground substrate temperature $(\mathrm{r}>0.5)$, and with the decrease in carbonate content $(\mathrm{r}<-0.5)$ (Table 2, Fig. 2).

The polygons of the ecospaces based on samples with and without Protura largely overlapped, with the centroids of both groups close to each other (Fig. 2). Protura occupied most of the ecospace of the entrance areas of the 60 caves under study. They were absent only in very dry/wet sections, and very cold sections with substrates very poor or rich in organic matter. The t-test between EPCs, with and without Protura, returned a non-significant difference between the ecospaces $(\mathrm{EPC} 1: \mathrm{t}=0.07, \mathrm{df}=106, \mathrm{p}=0.946 ; \mathrm{EPC} 2$ : $\mathrm{t}=0.83, \mathrm{df}=106, \mathrm{p}=0.407)$.

A Chi-square test showed no significant relation between the frequencies of Protura presence or absence and the main cover type in the landscape with the caves $\left(x^{2}=3.80, d f=5, p=0.578\right)$. Most caves with Protura were on the southern slopes (circular mean = $186.3^{\circ} ; 95 \%$ confidence $96.3^{\circ}-276.3^{\circ}$ ). No significant differences were found when examining the variability in slope azimuths between the caves with and without Protura (Watson-Williams equal means U test $=1.16$, $\mathrm{df}=57, \mathrm{p}=0.286 ;$ a Mardia-Watson-Wheeler $\mathrm{W}$ test $=4.30, \mathrm{df}=56, \mathrm{p}=0.117)$.

Abundance of Protura decreased significantly with increasing distance from the entrance (Estimated $\beta \pm S E$ : $-0.1151 \pm 0.0345, \mathrm{p}=0.001)$ and from the soil surface (Estimated $\beta \pm S E$ : $-0.0855 \pm 0.0286, \mathrm{p}=$ 0.003). The effect of both variables on the abundance of Protura is illustrated in Figure 3.

Estimated densities of Protura were very low in all the caves under study, with maximum values of 68 and 32 specimens $/ \mathrm{m}^{2}$ at the entrance of Ovčje peklo and Ihanšica, respectively.

Protura from 15 caves, totally 286 individuals, were examined in more detail. Identified Protura

Table 3. Descriptive statistics of the sampling sections with Protura. N, number of sampling sections; Mean, arithmetic mean; StD, standard deviation; min, minimum; max, maximum. For description of variables, see the first paragraph in the Field methods.

\begin{tabular}{|l|c|c|}
\hline \multicolumn{1}{|c|}{ Variables } & Acronyms & N; Mean \pm StD (min-max) \\
\hline Number of Protura specimens & Abundance & $48 ; 2.5 \pm 0.4(1-17)$ \\
\hline Distance from the entrance & DistE $[\mathrm{m}]$ & $48 ; 5.4 \pm 7.4(0-24)$ \\
\hline Distance from the surface & DistS [m] & $48 ; 6.4 \pm 4.8(0-20)$ \\
\hline Air temperature & Tair $\left[{ }^{\circ} \mathrm{C}\right]$ & $43 ; 8.8 \pm 5.1(1.0-22.0)$ \\
\hline Ground temperature & Tgr $\left[{ }^{\circ} \mathrm{C}\right]$ & $48 ; 7.5 \pm 3.7(0.6-16.5)$ \\
\hline Relative air humidity & $\mathrm{RH}[\%]$ & $43 ; 89.3 \pm 11.8(64-100)$ \\
\hline Substrate moisture content & $\mathrm{MC}[\%]$ & $45 ; 21.2 \pm 14.7(0-53)$ \\
\hline Airflow & Airflow $\left[\log \mathrm{cm} \cdot \mathrm{s}^{-1}\right]$ & $48 ; 1.5 \pm 0.7(0-3)$ \\
\hline Organic material content & $\mathrm{OM}[\%]$ & $34 ; 14.3 \pm 17.9(1.5-85.9)$ \\
\hline pH of the ground substrate & $\mathrm{pHgr}[\mathrm{pH}-\mathrm{unit}]$ & $34 ; 8.0 \pm 0.7(4.4-8.7)$ \\
\hline Carbonate content & $\mathrm{CC}[\%]$ & $34 ; 24.9 \pm 24.5(0.0-87.0)$ \\
\hline
\end{tabular}




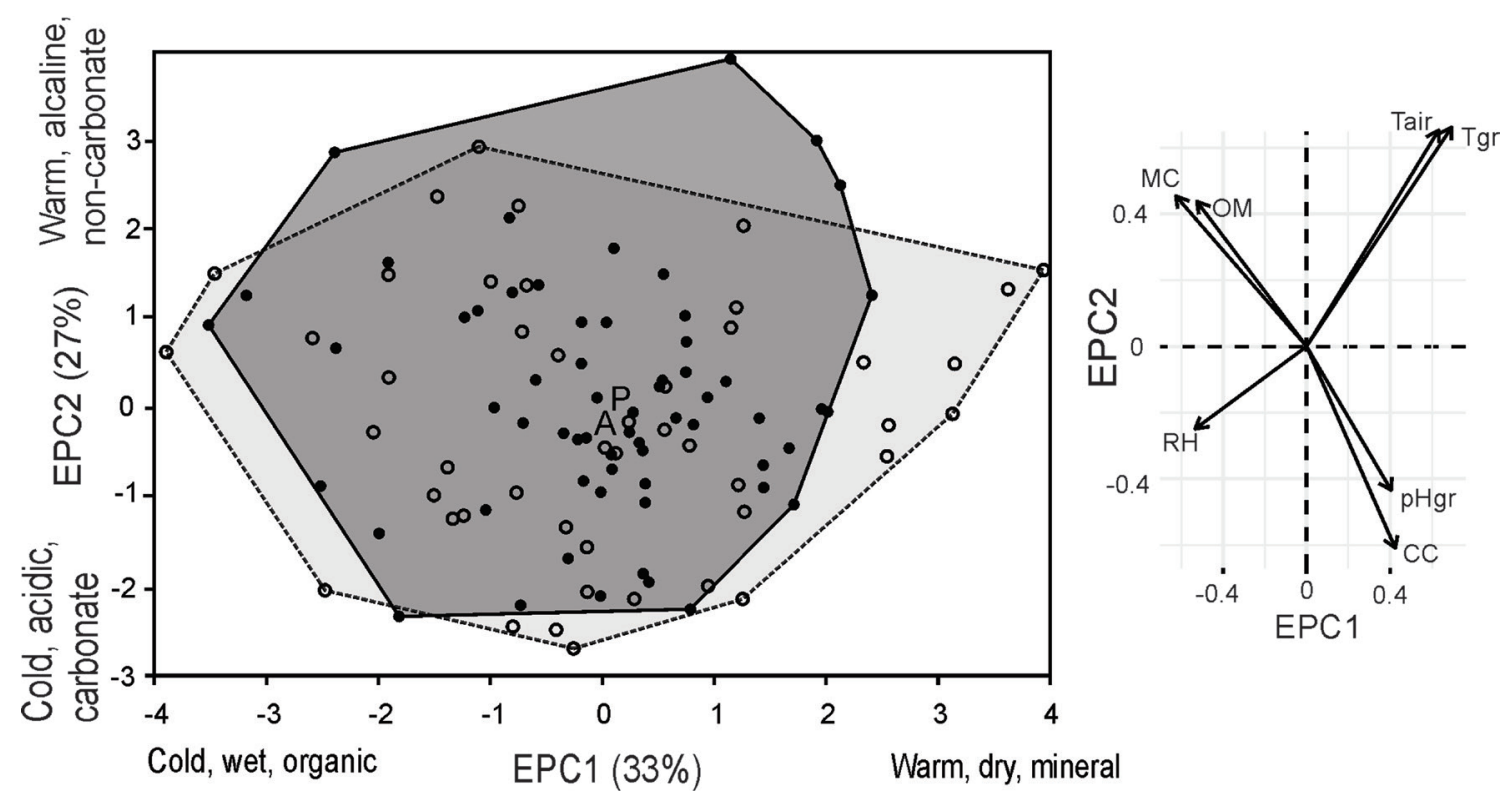

Fig. 2. Bivariate plot of the cave-ecospace polygons onto the first two ecological principal components (EPCs) derived from ordination of seven environmental variables. The percentage of variance explained by individual EPCs is in parentheses. The character vector diagram illustrates the relative contribution of the original variables (see Table 3 for acronyms) to each EPCs. The polygon with the Protura ecospace is dark grey, with black dots and outlined by solid line, and that without Protura is light grey, with open dots and outlined by the dotted line. Centroid identifiers: P - Protura present; A - Protura absent.
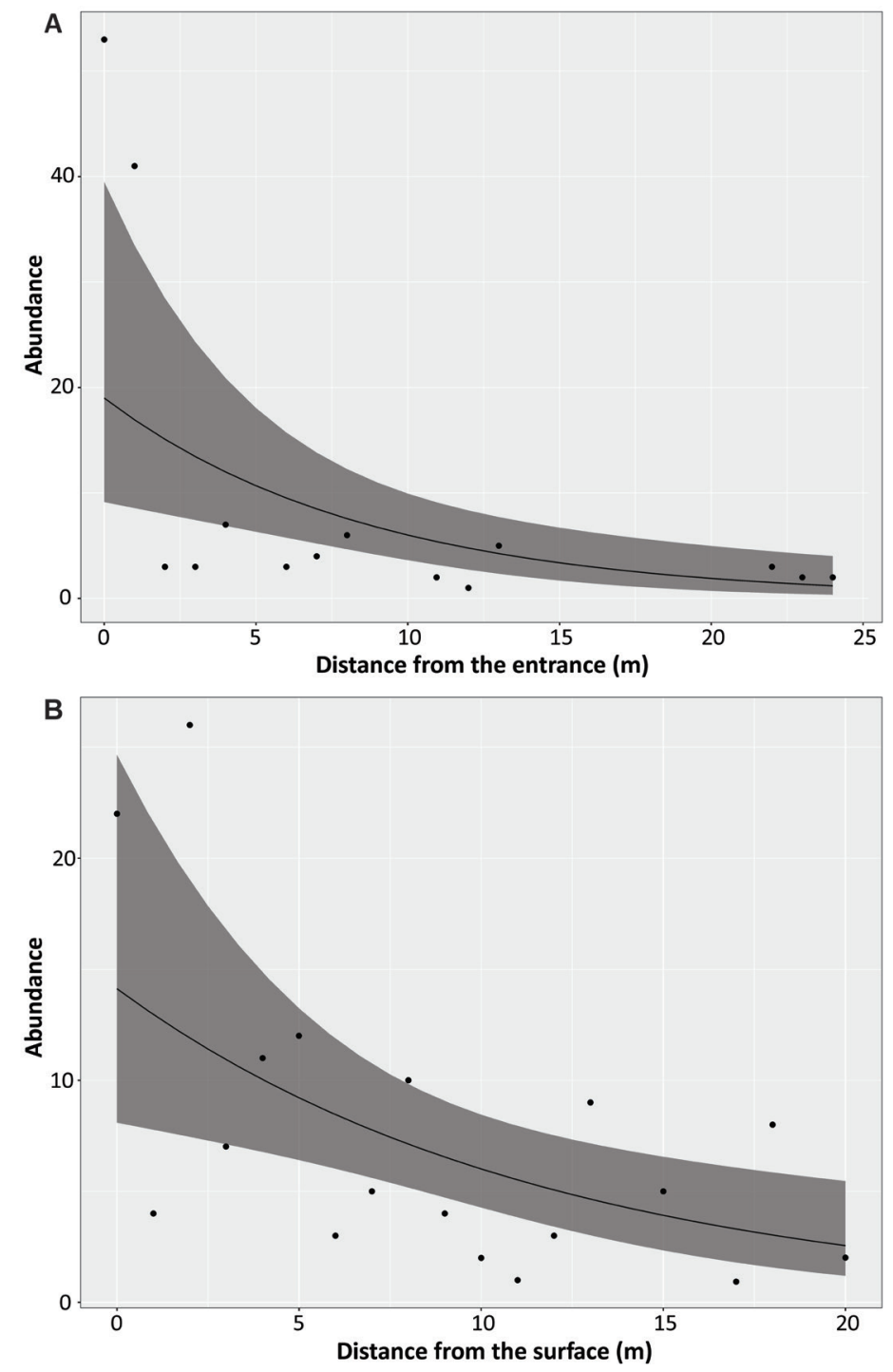

Fig. 3. Predicted relationships between the abundance of Protura and $(A)$ distance from the entrance, and (B) distance from the surface obtained from the generalized mixed models. Black lines are predicted values, while grey areas are $95 \%$ confidence intervals. belonged to five genera and ten species (Table 4). Seven of them were new to Slovenia: Acerentulus rafalskii Szeptycki, 1979, Acerentomon affine Bagnall, 1912, A. balcanicum Ionesco, 1933, A. maius Berlese, 1908, Acerella muscorum (Ionesco, 1930), Eosentomon armatum Stach, 1926 and E. transitorium Berlese, 1908. Further, an unidentified species of the genus Ionescuellum Tuxen, 1960 is also new to Slovenia. Among the identified Protura, 260 belong to the order Acerentomata, two belong to the family Hesperentomidae, genus Ionescuellum, and the others belong to the family Acerentomidae, genera Acerentulus, Acerentomon and Acerella. The remaining 26 specimens belong to the order Eosentomata, genus Eosentomon. These proturans did not show any obvious morphological differences from those of the same species collected elsewhere in Europe outside the caves.

The age ratios of juveniles to adults in spring and summer (the seasons accounting for the large majority of identified specimens), were 0.55 and 0.31 respectively, and differing at a significant level $\left(x^{2}=3.9454, \mathrm{df}=1, \mathrm{p}<0.05\right)$. The sex ratio of the five dominant species is shown in Table 5 . For three of the species (A confinis, A. maius, and A. meridionale) the populations contained a greater number of females at a statistically significant level.

\section{DISCUSSION}

In this study, no differences were found in terms of the ecological characteristics between caves with and without Protura. The environmental analyses showed that Protura were mainly found close to the entrance of the cave. However, a small number of individuals were recorded deeper inside, probably having fallen or washed into the cave from surface soils through vertical fissures in the bedrock. The role 
Table 4. Protura identified in 15 Slovenian caves. For cave ID, see Table 1. The following abbreviations were adopted: LI = Larva I, LII = Larva II, MJ = Maturus Junior, $\mathrm{PI}=$ Pre-Imago, F = Female, M = Male, Un = Unidentified, Aut = Autumn, Spr = Spring, Sum = Summer.

\begin{tabular}{|c|c|c|c|c|c|c|c|c|c|c|c|c|c|c|c|c|}
\hline ID-Cave & 3 & 28 & 31 & 32 & 32 & 35 & 36 & 37 & 38 & 40 & 42 & 45 & 48 & 49 & 52 & 59 \\
\hline Season & Spr & Spr & Spr & Spr & Sum & Spr & Spr & Spr & Spr & Sum & Spr & Spr & Spr & Sum & Spr & Aut \\
\hline Ionescuellum sp. & & & & $1 \mathrm{~F}$ & & & & $1 \mathrm{MJ}$ & & & & & & & & \\
\hline Acerentulus sp. & & & & & & & $1 \mathrm{~F}$ & & & $2 \mathrm{M}$ & & $1 \mathrm{Un}$ & $\begin{array}{c}2 \mathrm{M} \\
6 \mathrm{~F} \\
2 \mathrm{MJ} \\
1 \mathrm{LI}\end{array}$ & & & \\
\hline Acerentulus confinis & & & & $1 \mathrm{~F}$ & $\begin{array}{l}1 \mathrm{M} \\
2 \mathrm{~F}\end{array}$ & & & $\begin{array}{c}4 \mathrm{M} \\
9 \mathrm{~F} \\
7 \mathrm{PI} \\
11 \mathrm{MJ}\end{array}$ & & $5 \mathrm{~F}$ & & $1 \mathrm{~F}$ & & & & \\
\hline Acerentulus rafalskii & & & & & & & & & & & & & & $1 \mathrm{M}$ & & $1 \mathrm{M}$ \\
\hline Acerentomon sp. & $\begin{array}{c}1 \mathrm{LI} \\
2 \mathrm{Un}\end{array}$ & & $1 \mathrm{LI}$ & $1 \mathrm{LI}$ & $1 \mathrm{Un}$ & & $\begin{array}{l}1 \mathrm{MJ} \\
1 \mathrm{Un}\end{array}$ & & 2LII & & & & & $1 \mathrm{MJ}$ & & $\begin{array}{l}1 \mathrm{LII} \\
1 \mathrm{LI}\end{array}$ \\
\hline $\begin{array}{l}\text { Acerentomon doderoi } \\
\text { group }\end{array}$ & & & & & & & & & $1 \mathrm{LI}$ & & & & & & & \\
\hline $\begin{array}{l}\text { Acerentomon } \\
\text { microrhinus group }\end{array}$ & & & & & $\begin{array}{l}1 \mathrm{M} \\
2 \mathrm{PI}\end{array}$ & & & & $\begin{array}{l}1 \mathrm{~F} \\
1 \mathrm{LI}\end{array}$ & & $\begin{array}{l}1 \mathrm{M} \\
2 \mathrm{~F}\end{array}$ & & & & & \\
\hline Aceremtomon affine & & & & & & $\begin{array}{l}1 \mathrm{M} \\
2 \mathrm{~F}\end{array}$ & $\begin{array}{c}18 \mathrm{M} \\
19 \mathrm{~F} \\
2 \mathrm{PI} \\
7 \mathrm{MJ} \\
9 \mathrm{LII} \\
7 \mathrm{LI} \\
4 \mathrm{Un} \\
\end{array}$ & & & & & & & & & \\
\hline $\begin{array}{l}\text { Acerentomon } \\
\text { balcanicum }\end{array}$ & & & & $\begin{array}{l}2 \mathrm{M} \\
2 \mathrm{~F}\end{array}$ & $\begin{array}{c}15 \mathrm{M} \\
25 \mathrm{~F} \\
7 \mathrm{PI} \\
2 \mathrm{MJ} \\
1 \mathrm{LII} \\
4 \mathrm{Un}\end{array}$ & & & & & & & & & & & \\
\hline Acerentomon italicum & & & & & & & & & & & & & & & & $1 \mathrm{~F}$ \\
\hline Acerentomon maius & $\begin{array}{c}15 \mathrm{~F} \\
3 \mathrm{MJ} \\
1 \mathrm{LI}\end{array}$ & $1 \mathrm{M}$ & & & & & & & & & & & & & & \\
\hline $\begin{array}{l}\text { Acerentomon } \\
\text { meridionale }\end{array}$ & & & & & $\begin{array}{c}4 \mathrm{M} \\
12 \mathrm{~F} \\
1 \mathrm{PI} \\
3 \mathrm{MJ} \\
4 \mathrm{LII}\end{array}$ & & & & & & & & & & & \\
\hline Acerella muscorum & & & & & & & & $2 \mathrm{~F}$ & & & & & & & $3 F$ & $1 \mathrm{~F}$ \\
\hline Eosentomon sp. & & & & & & & & $\begin{array}{c}1 \mathrm{M} \\
3 \mathrm{Un}\end{array}$ & & & $\begin{array}{c}1 \mathrm{M} \\
2 \mathrm{~F} \\
1 \mathrm{Un}\end{array}$ & & & & $1 \mathrm{Un}$ & \\
\hline $\begin{array}{l}\text { Eosentomon } \\
\text { delicatum group }\end{array}$ & & & & & & & & $\begin{array}{l}2 \mathrm{M} \\
5 \mathrm{~F}\end{array}$ & & & & & & & & \\
\hline $\begin{array}{l}\text { Eosentomon } \\
\text { transitorium group }\end{array}$ & & & & & & & & & & & $\begin{array}{l}1 \mathrm{M} \\
2 \mathrm{~F}\end{array}$ & & & & & \\
\hline Eosentomon armatum & & & $\begin{array}{c}2 \mathrm{M} \\
1 \mathrm{~F} \\
1 \mathrm{MJ}\end{array}$ & & & & & & & & & & & & & \\
\hline $\begin{array}{l}\text { Eosentomon } \\
\text { transitorium }\end{array}$ & & & & & & & & $1 \mathrm{M}$ & & & & & & & $\begin{array}{l}1 \mathrm{M} \\
1 \mathrm{~F}\end{array}$ & \\
\hline Total & 22 & 1 & 5 & 7 & 85 & 3 & 69 & 46 & 5 & 7 & 10 & 2 & 11 & 2 & 6 & 5 \\
\hline
\end{tabular}

of the cave-entrance habitat, as an ecotone environment, has been discussed since the first empirical studies on cave biodiversity (e.g., Peck, 1976; Prous et al., 2004, 2015; White, 2012). In some cases, this ecotone habitat is also characterized by high endemism (e.g., Yao et al., 2016), but it was not the case with Protura in our study; specimens in the caves belonged to the same species elsewhere inhabiting soils of epigean habitats. This result supports the previously available published data on Protura collected in caves (Vandel, 1964; Neuherz, 1974, 1975; Nosek, 1975; Novak,
2005; Szeptycki, 2007; Galli et al., 2019b; Shrubovych \& Georgiev, 2020).

Density estimates recorded in the caves under study were lower than those of some hundreds/thousands individuals $/ \mathrm{m}^{2}$ previously known from literature for surface soil samples (Galli et al., 2019a). This is probably due to both a low amount of soil, and a limited volume of the substrate per unit area in such habitats.

The analyzed samples were too small to examine thoroughly the life cycles of single species. The overall 
Table 5. Sex ratio calculated for five dominant species of Protura in Slovenian caves. $M=$ number of males, $F=$ number of females, sex ratio $M / F, X^{2}$ and relative $p$-values for the sex ratio.

\begin{tabular}{|l|c|c|c|c|c|}
\hline \multicolumn{1}{|c|}{ Specie } & M & F & Sex ratio & $\mathbf{x}^{\mathbf{2}}$ (df = 1) & $\mathbf{p}$ \\
\hline Acerentulus confinis & 5 & 18 & 0.28 & 7.35 & $<0.01$ \\
\hline Acerentomon affine & 19 & 21 & 0.90 & 0.05 & 0.823 \\
\hline Acerentomon balcanicum & 17 & 27 & 0.63 & 1.15 & 0.283 \\
\hline Acerentomon maius & 1 & 15 & 0.07 & 12.25 & $<0.01$ \\
\hline Acerentomon meridionale & 4 & 12 & 0.33 & 4.00 & $<0.05$ \\
\hline
\end{tabular}

analysis of the developmental instars of specimens evidenced the presence of juveniles in three seasons (spring, summer and autumn), indicating that in Slovenia Protura reproduce almost throughout the warm part of the year with a peak during spring. This result confirms the already investigated phenologies of some species (Galli et al., 2019a). For five dominant species it was possible to analyze the sex ratio. The results are similar to those obtained for the same species in Italy (Galli et al., 2019b): A. confinis, A. maius, and $A$. meridionale populations showed a bias towards females, while in A. affine and A. balcanicum populations showed a balanced sex ratio (for further information see also Galli et al., 2019b).

This research has increased the checklist of Protura species in Slovenia through the addition of: Acerentulus rafalskii, previously known only from Poland (Szeptycki, 2007); Acerentomon affine, widespread in Western Europe (Szeptycki, 2007); A. balcanicum in Southeast Europe and Ukraine (Szeptycki, 2007); A. maius in Central Europe and Italy (Szeptycki, 2007); Acerella muscorum, distributed in West and Central Europe and the Near East, and already recorded from all the countries surrounding Slovenia (Austria, Hungary, Italy, and Bosnia and Herzegovina) (Szeptycki, 2007); Eosentomon armatum and E. transitorium, both with a wide European distribution (Shrubovych \& Bernard, 2018). However, Szeptycki (2007) considered the bibliographic record of Acerella tiarnea doubtful. The new record of $A$. muscorum mentioned above probably confirms the misidentification. Therefore, the current number of Protura species in Slovenia is 15 .

Our research, the first one specifically concerning Protura in caves, confirms the absence of any morphological adaptations to such an environment in this taxon (Pass \& Szucsich, 2011). Furthermore, in the collection of one of the authors (LG), some specimens of Acerentomon doderoi, A. gallicum Ionesco, 1933 and $A$. maius come from two caves in Liguria (NW-Italy), and three females of Berberentulus travassosi (Silvestri, 1938) come from a Minas-Gerais (Brazil) cave. Morphologically, all of them correspond to the species description based on specimens collected from surface soils (LG, unpublished data).

All the evidence shown above supports the hypothesis that Protura have entered caves passively within debris/litter by accident, mostly close to the entrance. In terms of speleobiological, ecological classification, they must be ranked among “accidentals" (sensu Barr, 1967). Eventually, in some other regions, Protura might migrate from soils or mesovoid shallow substratum (MSS) (Mammola et al., 2016) into adjacent cave portions and vice versa over the year, but this does not seem to happen in Central Europe.

\section{CONCLUSION}

Protura is probably the least known group of hexapods, with scattered and fragmentary literature records from caves. This is the first contribution dealing exclusively with this topic, which despite the small number of specimens found provides important knowledge on proturans in caves because the research is based on over 6000 samples taken from caves in Slovenia.

Our research confirms previous observations that proturans occupy cave ecosystems through passive colonization after their accidental introduction from the surface soil of habitats near the entrance to, and above, caves. None of the identified species displayed morphological adaptations specific to a cave environment. And although the density of proturans was lower than that found in surface soils elsewhere, their presence recorded mainly near cave entrances was related with the 'fallen-in' organic matter onto these sites.

\section{ACKNOWLEDGEMENTS}

The authors are indebted to friends and colleagues, especially Valika Kuštor, Ignac Sivec, Mojmir Štangelj, and Ljuba Slana Novak, and some students, for the help in field investigations. This study received funding support from Javna agencija za raziskovalno dejavnost Republike Slovenije (Slovenian Research Agency) through research core funding no. P10403 and J1-2457 (FJ), Karst Research programme (P6-0119; PK) and Project "Development of research infrastructure for the international competitiveness of the Slovenian RRI space - RIi-SI-LifeWatch" (the operation is co-financed by the Ministry of Education, Science and Sport, Republic of Slovenia, and the European Union from the European Regional Development Fund; FJ and PK). We are indebted to Stefano Mammola and to an anonymous referee for their insightful comments and valuable suggestions that helped greatly improving the manuscript. Last, but not least, many thanks also to Tony Molyneux who carefully checked the English of our manuscript.

Authorship statement: LG prepared and identified Protura slides, performed some analyses and wrote the paper with the input from the other authors. TN designed the field research, collected the bulk of the material examined and contributed to the field 
data. PK took part in the field research, FJ and PK performed statistical analyses of the field data, and TN, FJ, and PK contributed to the corresponding texts.

\section{REFERENCES}

Balkenhol, B., 1996. Activity range and dispersal of the Protura Acerentomon nemorale (Arthropoda: Insecta). Pedobiologia, 40, 212-216.

Barr, T.C.Jr., 1967. Observations on the ecology of caves. The American Naturalist, 101, 475-491.

Bole, J., Drovnik, B., Mršić, N., Sket, B., 1993. Endemic animals in hypogean habitats in Slovenia. Naše jame, 35, 43-55.

Cardoso, P., Erwin, T.L., Borges, P.A.V., New, T.R., 2011. The seven impediments in invertebrate conservation and how to overcome them. Biological Conservation, 144(11), 2647-2655.

https://doi.org/10.1016/j.biocon.2011.07.024

Culver, D.C., Trontelj, P., Zagmajster, M., Pipan, T., 2012. Paving the way for standardized and comparable subterranean biodiversity studies. Subterranean Biology, 10, 43-50. https://doi.org/10.3897/subtbiol.10.4759

Culver, D.C., Deharveng, L., Bedos, A., Lewis, J.J., Madden, M., Reddel, J.L., Sket, B., Trontelj, P., White, D., 2006. The mid-latitude biodiversity ridge in terrestrial cave fauna. Ecography, 29, 120-128. https://www.jstor.org/stable/3683502

Culver, D.C., Pipan, T., 2019. The biology of caves and other subterranean habitats ( $2^{\text {nd }}$ Ed.). Oxford University Press, Oxford, $301 \mathrm{p}$.

Dray, S., Dufour, A.-B., Thioulouse, J., 2020. Analysis of ecological data: Exploratory and euclidean methods in environmental sciences. $\mathrm{R}$ package Version 1.7-16. https:/ / CRAN.R-project.org/package=ade4

Ficetola, G.M., Canedoli, G., Stoch F., 2018. The Racovitzan impediment and the hidden biodiversity of unexplored environments. Conservation Biology, 33, 214-216. https://doi.org/10.1111/cobi.13179

Galli, L., Bartel, D., Capurro, M., Pass, G., Sarà, A., Shrubovych, J., Szucsich, N., 2016. Redescription and review of the most abundant conehead in Italy: Acerentomon italicum Nosek, 1969 (Protura: Acerentomidae). Italian Journal of Zoology, 83(1), 4358. https://doi.org/10.1080/11250003.2015.1114686

Galli, L., Capurro, M., Colasanto, E., Molyneux, T., Murray, A., Torti, C., Zinni, M., 2019a. A synopsis of the ecology of Protura (Arthropoda: Hexapoda). Revue suisse de Zoologie, 126(2), 155-164.

https://doi.org/10.5281/zenodo.3463443

Galli, L., Capurro, M., Molyneux, T., Torti, C., Zinni, M., 2019b. Ecology of Italian Protura. Pedobiologia, 73, 20-28. https://doi.org/10.1016/j.pedobi.2019.01.004

Galli, L., Rellini, I., 2020. The geographic distribution of Protura (Arthropoda: Hexapoda): a review. Biogeographia - The Journal of Integrative Biogeography, 35, 51-69.

https://doi.org/10.21426/B635048595

Halikia, I., Zoumpoulakis, L., Christodoulou, E., Prattis, D., 2001. Kinetic study of the thermal decomposition of calcium carbonate by isothermal methods of analysis. The European Journal of Mineral Processing and Environmental Protection 1(2), 89-102. https://doi.org/10.21426/B635048595

Hammer, Ø., Harper, D.A.T., Ryan, P.D., 2001. PAST: Paleontological statistics software package for education and data analysis. Palaeontologia Electronica, 4, 1-9. http://folk.uio.no/ohammer/past
Kassambara, A., Mundt, F., 2020. factoextra: Extract and visualize the results of multivariate data analyses. $\mathrm{R}$ package version 1.0.7. https://CRAN.R-project.org/package=factoextra

Kozel, P., Pipan, T., Mammola, S., Culver, D.C., Novak, T., 2019. Distributional dynamics of a specialized subterranean community oppose the classical understanding of the preferred subterranean habitats. Invertebrate Biology, 138, e12254. https://doi.org/10.1111/ivb.12254

Mammola, S., 2018. Finding answers in the dark: caves as models in ecology fifty years after Poulson and White. Ecography, 41, 1-21.

https://doi.org/10.1111/ecog.03905

Mammola, S., Giachino, P.M., Piano, E., Jones, A., Barberis, M., Badino, G., Isaia, M., 2016. Ecology and sampling techniques of an understudied subterranean habitat: the Milieu Souterrain Superficiel (MSS). Science Nature, 103, 88. https://doi.org/10.1007/s00114-016-1413-9

Mammola, S., Souza, M.F.V.R., Isaia, M., Lopes Ferreira, R., in press. Global distribution of microwhip scorpions (Arachnida: Palpigradi). Journal of Biogeography.

Neuherz, H.V., 1974. Der erste Höhlenfund einer Proture (Insecta, Apterygota) in Österreich. Die Höhle, 25, 25-30.

Neuherz, H.V., 1975. Die Landfauna der Lurgrotte (Teil I). Sitzungsberichte der österreichischen Akademie der Wissenschaften (Mathem.-naturw. Kl.), 183, 159-285.

Nosek, J., 1973. European Protura. Genève, Muséum d'Histoire Naturelle, Geneva, 345 p.

Nosek, J., 1975. Niches of Protura in biogeocoenoses. Pedobiologia, 15, 290-298.

Nosek, J., 1977a. Adaptations in Protura. Revue d'Écologie et de Biologie du Sol, 14(1), 217-224.

Nosek, J., 1977b. Proturan synusies and niche separation in the soil. Ecological Bulletins, 25, 138-142.

Novak, T., 2005. Terrestrial fauna from cavities in northern and central Slovenia, and a review of systematically ecologically investigated cavities. Acta Carsologica, 34(1), 169-210.

https://doi.org/10.3986/ac.v34i1.285

Novak, T., Lipovšek Delakorda, S., Senčič, L., Pabst, M.A., Janžekovič, F., 2004a. Adaptations in phalangiid harvestmen Gyas annulatus and G. titanus to their preferred water current adjacent habitats. Acta Oecologica, 26, 45-53.

https://doi.org/10.1016/j.actao.2004.03.004

Novak, T., Sambol, J., Janžekovič, F., 2004b. Faunal dynamics in the Železna jama cave. Acta Carsologica, 33, 249-267.

http://carsologica.zrc-sazu.si/downloads/332/ novak.pdf

Pass, G., Szucsich, N., 2011. 100 years of research on the Protura: many secrets still retained. Soil Organisms, 83(3), 309-334.

Peck, S.B., 1976. The effect of cave entrances on the distribution of cave inhabiting terrestrial arthropods. International Journal of Speleology, 8, 309-321.

Pretner, E., 1979. Podzemeljska koleopterološka fauna umetnih votlin. [Die unterirdische Käferfauna in künstlichen Hohlräumen.] Acta Entomologica Jugoslavica, 15(1-2), 89-102.

Prous, X., Lopes Ferreira, R., Jacobi, C.M., 2015. The entrance as a complex ecotone in a Neotropical cave. International Journal of Speleology, 44(2), 177-189. https://doi.org/10.5038/1827-806X.44.2.7

Prous, X., Lopes Ferreira, R., Parentoni Martins, R., 2004. Ecotone delimitation: epigean-hypogean transition in cave ecosystems. Austral Ecology, 29, 374-382. https://doi.org/10.1111/j.1442-9993.2004.01373.x 
Qiao, H., Peterson, A.T., Ji, L., Hu, J., 2017. Using data from related species to overcome spatial sampling bias and associated limitations in ecological niche modeling. Methods in Ecology and Evolution, 8(12), 1804-1812. https://doi.org/10.1111/2041-210X.12832

$\mathrm{R}$ Core Team, 2020. R: A language and environment for statistical computing. R Foundation for Statistical Computing. Vienna, Austria. https://www.R-project.org/ Ripley, B., Venables, B., Bates, D. M., Hornik, K., Gebhardt, A., Firth, D., 2020. Support functions and datasets for Venables and Ripley's MASS. R package Version 7.3-53. https://cran.r-project.org/package

Sendra, A., Palero, F., Jiménez-Valverde, A., Reboleira, A.S.P.S., 2020. Diplura in caves: diversity, ecology, evolution and biogeography. Zoological Journal of the Linnean Society, 20, 1-15. https://doi.org/10.1093/zoolinnean/zlaa116

Sheppard, S.C., Addison, J.A., 2008. Soil Sample Handling and Storage. In: Carter, M.R., Gregorich, E.G. (Eds.), Soil sampling and methods of analysis ( $2^{\text {nd }}$ Ed.), Canadian Society of Soil Science, Taylor \& Francis, Boca Raton, p. 39-49.

Shrubovych, J., Bernard, E., 2018. A key for the determination of European species of Eosentomon Berlese, 1909 (Protura, Eosentomata, Eosentomidae). ZooKeys, 742, 1-12. https://doi.org/10.3897/zookeys.742.22664

Shrubovych, J., Georgiev, D., 2020. Protura records in Sarnena Goura Mountains. In Georgiev, D., Bechev,
D., Yancheva, V. (Eds.), Fauna of Sarnena Sredna Gora Mts, Part 1. Zoonotes, Suppl. 9, 43-46.

Smith, A.B., Godsoe, W., Rodríguez-Sánchez, F., Wang, H.H., Warren, D., 2019. Niche estimation above and below the species level. Trends in Ecology \& Evolution, 34(3), 260-273.

https://doi.org/10.1016/j.tree.2018.10.012

Szeptycki, A., 2007. Catalogue of the world Protura. Acta Zoologica Cracoviensia, 50B(1), 1-210.

Tuxen, S.L., 1978. Protura (Insecta) and Brazil during 400 million years of continental drift. Studies on Neotropical Fauna and Environment, 13(1), 23-50.

Vandel, A., 1964. Biospéologie. La biologie des animaux cavernicoles. Guthier-Villars, Paris, 619 p.

Yao, Z., Dong, T., Zheng, G., Fu, J., Li, S., 2016. High endemism at cave entrances: a case study of spiders of the genus Uthina. Scientific Reports, 6, 35757. https://doi.org/10.1038/srep35757

White, W.B., 2012. Entrances. In: White, W.B., Culver, D.C. (Eds.), Encyclopedia of caves (2 ${ }^{\text {nd }}$ Ed.). Elsevier, Amsterdam, p. 280-284.

Zuur, A.F., Ieno, E.N., Walkerm, N.J., Savaliev, A.A., Smith, G.M., 2009. Mixed effect models and extensions in ecology with R. Springer, New York, 574 p.

Zuur, A.F., Ieno, E.N., 2016. A protocol for conducting and presenting results of regression-type analyses. Methods in Ecology and Evolution, 7(6), 636-645. https://doi.org/10.1111/2041-210X.12577 